\title{
Effects of carbachol administration in cattle grazing tall larkspur-infested range
}

\author{
JAMES A. PFISTER AND GARY D. MANNERS
}

Pfister is range sciemist, USDA-ARS Poisonous Plant Research Lab., l150 E. 1400 N., Logan. Utah $\$ 4321$. Manners is research chemist, USDA-ARS Westem Regional Research Lab., Albany, Calif. 94710.

\begin{abstract}
Tall larkspur (Delphinium barbeyi L. Huth.) toxicosis of cattle is a serious problem on western USA mountain rangelands. Manipulating the ruminal environment may decrease the susceptibility of cattle to larkspur intoxication. The cholinergic drug carbachol can greatly increase salivary flow and fluid passage rate in ruminants. Our objectives were to: (1) determine if chronic administration of carbachol altered ruminal fluid passage rate, ruminal $\mathrm{pH}$, or water intake in grazing cattle, and (2) evaluate mineral salt supplementation as a prophylactic procedure for cattle grazing larkspur-infested rangelands. The study was conducted during summer of 1990 and 1991 near Yampa, Colo. Twelve heifers were divided randomly into 3 treatment groups: (1) carbachol administered at $0.01 \mathrm{mg}^{\circ} \mathrm{kg}^{-1} \cdot \mathrm{day}^{-1}$ via subcutaneous osmotic minipumps; (2) mineral-salt supplement

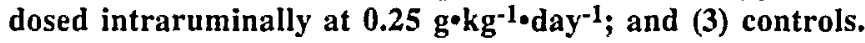
Administration of carbachol either had no effect or a negative effect on ruminal fluid passage rate, ruminal $\mathrm{pH}$, saliva production, and water intake compared with the controls. Carbachol had few consistent effects on serum electrolyte concentrations compared to the controls. Treatments did not influence cattle diet selection; cattle ate no larkspur during 1990, but selected larkspur for $16 \%$ of their diets during August, 1991. There was no indication that supplementation with mineral salt would attenuate larkspur toxicosis through increased dilution rates, or decreased larkspur consumption. Our results indicate that neither carbachol nor mineral supplementation will reduce animal susceptibility to larkspur toxicosis.
\end{abstract}

Key Words: cholinergic, Delphinium barbeyi, diet selection, alkaloids, animal nutrition, toxic plants, rate of passage

Tall larkspur (Delphinium barbeyi L. Huth.) poisoning is a major cause of death in cattle grazing on mountain ranges in the western U.S. (Ralphs et al. 1988). Tall larkspur contains many diterpenoid alkaloids (Manners et al. 1992), but the most toxic

\footnotetext{
We thank Kermit Price. Tracey Wcber. Jeff Stout and Greg Houston for valuable asistance dring the study. We apprecrate the assistance of Nancy Peterson, DVM. This protocol was approved by the Instututional Animal Care and Use Committeej Utah State University, Logan We also thank Drs. Mike Galyean and Ken Olson for their helpful reviews of an earlier draft of the manuscript. Manuscript accepted 18 Nov. 1994.
}

major alkaloid is methyllycaconitine (MLA; Manners et al. 1993). Methyllycaconitine blocks post-synaptic acetylcholine receptors in the central and peripheral nervous systems (Dobelis et al. 1993), leading to eventual respiratory failure. An oral dose of about $11 \mathrm{mg} \mathrm{MLA} / \mathrm{kg}$ of body weight causes collapse in cattle (Pfister et al. 1994a). Tall larkspur alkaloids are soluble over a $\mathrm{pH}$ range of 4.5 to 6.6 (Manners et al. 1993); thus, ruminal pH may affect absorption and eventual toxicity.

There is a family of drugs (termed acetylcholine receptor stimulants) that may directly (Pfister et al. 1994b) or indirectly mitigate MLA toxicity; one such drug is carbachol (carbamylcholine chloride ${ }^{1}$ ). It is a long-acting cholinomimetic drug that activates cholinergic receptors at both nicotinic and muscarinic sites (Taylor 1990). Carbachol administration results primarily in increased gut motility (Gerring 1989, Croom et al. 1990). Weidmeier et al. (1987) found that carbachol administration to dairy cattle increased ruminal $\mathrm{pH}$, fluid dilution rate, and rate of particulate passage. Many effects of carbachol have been attributed to increased salivary flow (Croom et al. 1990). Carbachol at higher doses also affects skeletal muscle as a result of agonistic effects at nicotinic receptor sites (Taylor 1990, Davis 1993).

Carbachol has not been used in grazing livestock; hence, our first objective was to determine if chronic administration of carbachol would alter ruminal $\mathrm{pH}$, fluid passage rate, water intake, and serum electrolyte concentrations in grazing cattle. We reasoned that if carbachol provoked measurable increases in salivation, ruminal fluid passage rate, and ruminal $\mathrm{pH}$ in grazing animals, the drug might alter larkspur intoxication through changes in solubility or dilution of larkspur alkaloids.

Severe larkspur losses have caused many livestock producers to try various preventive measures, including the widespread use of mineral-salt supplementation (Pfister and Manners 1991). This is an important issue due to the high cost of these special mineralsalt supplements. We postulated that if mineral supplements decrease cattle losses as some claim (Anderson 1982), this effect may result from increased ruminal dilution rates and water intake; however, a 2-year study found few ruminal effects from mineral supplementation (Pfister and Manners 1991). Our second objective was to confirm and extend our previous findings on effects

\footnotetext{
ISigma Chemical, St. Louis, Mo.
} 
(or lack thereof) of mineral salt supplement in cattle grazing larkspur-infested rangelands.

\section{Materials and Methods}

\section{Study Site}

The study was conducted during summer, 1990 (Trial 1) and 1991 (Trial 2) on the U.S. Forest Service North Hunt Allotment near Yampa, Colo. A 15-ha pasture was delineated with electric fence during both years. Cattle grazing was discontinued on the allotment for 3 years before our study began because of high losses from tall larkspur (C. Clementson, personal communication). More than one-half of the pasture had a forested overstory that consisted primarily of aspen (Populus tremuloides Michx.) and douglas fir (Pseudotsuga menziesii [Mirbel] Franco). Some dominant forb, shrub, and grass species were tall larkspur (Delphinium barbeyi L. Huth), false hellebore (Veratrum californicum Durand), cow parsnip (Heracletum lanatum Michx.), meadowrue (Thalictrum fendleri Engelm.), sweet cicely (Osmorhiza occidentalis [Nutt.] Torr.), snowberry (Symphoricarpos oreophilus Gray), and mountain brome (Bromus carinatus Hooker \& Arn.).

\section{Experimental Procedures}

Twelve ruminally cannulated Hereford $\mathrm{x}$ Angus $\mathrm{x}$ Charolois yearling heifers (mean body weight of $286 \pm 24 \mathrm{~kg}$ ) were used initially and during the second year. Each year, animals were assigned randomly to 1 of 3 treatments: (1) carbachol administered via osmotic minipumps; (2) mineral-salt supplement at 0.25 $\mathrm{g} \cdot \mathrm{kg}$ body weight ${ }^{-1} \cdot$ head $^{-1}$ day $^{-1}$; and (3) controls.

Cattle on the carbachol treatment were surgically implanted with osmotically controlled subcutaneous pumps ${ }^{2}$ (Theeuwes and Yum 1976) calibrated to deliver $0.01 \mathrm{mg}$ carbachol $\mathrm{kg}^{-1}$ day-1 for 28 days (Weidmeier et al. 1987). Pumps were $5.1 \mathrm{~cm}$ in length, and had a reservoir volume of $2 \mathrm{ml}$. Cattle on the mineralsalt treatment were given $0.25 \mathrm{~g}$ mineral salt $\cdot \mathrm{kg}$ body weight ${ }^{-1}$ day $^{-1}$ via ruminal cannulae. Composition of the mineral-salt mixture is given by Pfister and Manners 1991; the dose given was near the maximum amount consumed daily by grazing cattle (Pfister and Manners 1991). All animals had free access to water in a corral, and mineral was dosed when animals came in to drink each day or at midday. The control heifers had no access to mineral-salt supplement.

\section{Trial 1}

Cattle grazed on the larkspur-infested range from June 21 to August 7, 1990. Larkspur phenology was used to to define 4 grazing periods: bud stage ( 21 to 30 June), early flower (1 to 10 July), full flower (11 to 21 July). and pod stage (22 July to 7 August). During each period. most larkspur plants were in each phenological stage. In the bud stage, larkspur plants had not elongated reproductive racemes; during early flower most racemes had elongated but flowers had not opened.

Ruminal fluid passage rate $\left(\%\right.$ hour $\left.^{-1}\right)$ and ruminal $\mathrm{pH}$ were quantified on 3 dates during the study: 22 June, 11 July, and 7 August. All animals were dosed intraruminally at 0700 hours with $500 \mathrm{ml}$ of cobalt ethylenediaminetetraacetate (Co-EDTA; Uden et al. 1980), and allowed to graze thereafter. The Co-EDTA

\footnotetext{
2 Model 2ML 4 , Alza Co. Palo Alto. Calit 94304.
}

doses contained 2,280, 2,279, and 2,401 mg Co liter ${ }^{-1}$ for the 3 dates, respectively. Ruminal samples were taken at $0,4,8,12$, and 24 hours after dosing. Ruminal pH was determined immediately on each sample using a portable $\mathrm{pH}$ meter with combination electrode, after which samples were frozen at $-20^{\circ} \mathrm{C}$. After centrifugation at $10,000 \times \mathrm{g}$ for $20 \mathrm{~min}$, the supernatant fluid was filtered with a $0.2 \mu \mathrm{m}$ membrane filter. Cobalt concentrations were determined using atomic absorption spectrophotometry with an air-plus-acetylene flame, and fluid passage rate was calculated by regressing the natural logarithm of Co concentration on time. The reciprocal of the slope gave turnover time (hours). Ruminal volume (liters) was calculated by dividing Co dose by ruminal Co concentration extrapolated to time 0 . Fluid outflow rate (liters hour ${ }^{-1}$ ) was calculated as turnover time $x$ fluid passage rate. The mineral-salt mixture contained $\mathrm{Co}$, but ruminal fluid contained only 0 to $0.5 \mathrm{mg} \mathrm{Co} / \mathrm{liter}$ before dosing.

Water intake was measured over 2 consecutive days on 23 and 24 June, 13 and 14 July, and 2 and 3 August. Cattle could only drink in the corral, and on the day before water intake was measured, cattle were denied access to water at 1300 hours. On the subsequent 2 days, animals were confined at 1230 hours and individually given two, 5-min opportunities to drink while consumption was measured. Total water consumption over 2 days was divided by 2 to obtain a daily average. Saliva production was calculated as the difference between water intake and fluid outflow from the rumen (Jacques et al. 1989), and was not corrected for free water contained in consumed forage.

Blood samples were taken on 1 July, 19 July, and 6 August. After blood had clotted, serum was separated by centrifugation and frozen at $-20^{\circ} \mathrm{C}$. A standard chemistry panel was done at a medical center (Logan Regional Hospital) using established procedures and reagents.

Daily bite counts were used to determine animal diets (Pfister et al. 1988a,b; Pfister and Manners 1991). Individual animals were focally sampled in a predetermined random order. Beginning at daybreak, each animal was observed in turn for 5min before observing the next animal. After all animals had been observed, the process was repeated continually during all active grazing periods until dark. Bites were categorized as grasses, shrubs, other forbs, and larkspur bud, flower, pod. leaf, or leaf and stem. We defined an individual bite as a single cropping motion, always indicated by a head jerk, often accompanied by a visible sweep of the tongue, and independent of chewing motions.

Thitty, $0.25-\mathrm{m}^{2}$ plots were clipped at the beginning and the end of the grazing trial to measure standing crop. Ten plots were placed along each of 3 transects; clipped material was separated into larkspur, other forbs, and grasses, then dried and weighed. The grass and larkspur clipped samples (forb samples were lost) from 6 August were composited, subsampled, and analyzed for $\mathrm{Ca}, \mathrm{Co}, \mathrm{K}, \mathrm{Mg}, \mathrm{Na}$, and $\mathrm{P}$ concentrations using inductively coupled argon plasma spectrometry ${ }^{3}$ in an analytical laboratory at Utah State University.

Tall larkspur was collected periodically for analysis of methyllycaconitine (MLA) and 14-deacetylnudicauline (14-DAN). The material was analyzed for MLA and 14-DAN as outlined in Manners and Pfister (1993); results were reported by Pfister et al. (1994c).

\footnotetext{
3artell-Ash ICAP 9000 Plasma Spectrometer.
} 


\section{Trial 2}

Larkspur phenology was used to define 4 grazing periods during 1991: 26 June to 5 July (bud stage), 6 to 18 July (early flower), 19 July to 1 August (full flower), and 2 to 14 August (pod). The 2-year old heifers weighed $372 \pm 39 \mathrm{~kg}$ at the beginning of the trial.

Ruminal fluid passage rate and associated measures, including ruminal $\mathrm{pH}$. were determined on 29 June. $17 \mathrm{July}$, and 13 August. Procedures were identical to those described above for Trial 1 . except that Co was dosed at 2,180, 2,114, and 2,042 mg/liter for the 3 dates. respectively. Water intake and saliva production were measured as described for trial 1 on 1 and 2 July, 22 and 23 July, and 10 and 11 August. Blood samples were taken on 1 July, 19 July, and 14 August, and processed as described for Trial 1. Daily bite counts also were taken during all daylight hours when cattle were grazing.

Standing crop was determined on 28 June and 13 August 1991, by clipping 30 plots as described for Trial 1 . Forb, grass, and larkspur samples were composited for each plot by plant group, and ground to pass a $1-\mathrm{mm}$ screen in a Wiley mill. Five randomly chosen samples for each plant group and date were analyzed for $\mathrm{Ca}, \mathrm{Co}, \mathrm{K}, \mathrm{Mg}, \mathrm{Na}$, and $\mathrm{P}$ concentrations ( $\mathrm{n}=30$ ) using inductively coupled argon plasma spectrometry as noted above.

\section{Statistical Analyses}

A repeated measures ANOVA was used to analyze fluid passage rate and related variables, animal diets, water intake, and serum mineral concentrations. The model included treatment, animal nested within treatment as the error term for treatment, date, and the date $x$ treatment interaction. Specified contrasts were used to test for differences in carbachol vs. controls, and mineralsalt vs. controls. Contrasts also were used to compare individual periods (dates) if there was a significant $(P<0.05)$ main effect for period. Significant interactions were examined using the LSD procedure. Ruminal $\mathrm{pH}$ also was analyzed using a repeated measures ANOVA, except that an additional term for sampling hour was included in the model. A 2-way ANOVA (forage class and date) was used to analyze mineral concentrations in harvested plant samples from 1991. Significant $F$ tests $(P<0.05)$ for forage class or date were followed by the LSD procedure to separate means.

\section{Results}

\section{Trial 1 (1990)}

There was a treatment $x$ period interaction for fluid passage rate and turnover time. During July, the carbachol group had a lower fluid passage rate and higher turnover time than the controls (Table 1). During August, the controls differed in fluid passage rate from both carbachol and mineral-salt treatments; the mineral-salt treatment increased and the carbachol treatment decreased fluid passage rate. There were no differences in volume between the mineral-salt treatment or carbachol and the controls (Table 1). There were period effects, but no period $\times$ treatment interactions for volume or fluid outflow rate. The carbachol treatment had lower fluid outflow rate than did the controls, but no difference was noted between the mineral-salt treatment and the controls (Table 1).

There was a period effect on ruminal $\mathrm{pH}$, a period $\times$ sampling hour (data not shown) and a period $\times$ treatment interaction, but no period $x$ treatment $x$ hour interaction (Table 2). During June, ruminal $\mathrm{pH}$ was greater for controls than for either the mineralsalt or carbachol treatment groups.

Table 1. Ruminal fluid passage rate (\%/hour), volume (liters/kg of body weight), turnover time (hours), and fluid outflow rate (liters/hour) for cattle receiving carbachol or mineral during 1990 and 1991.

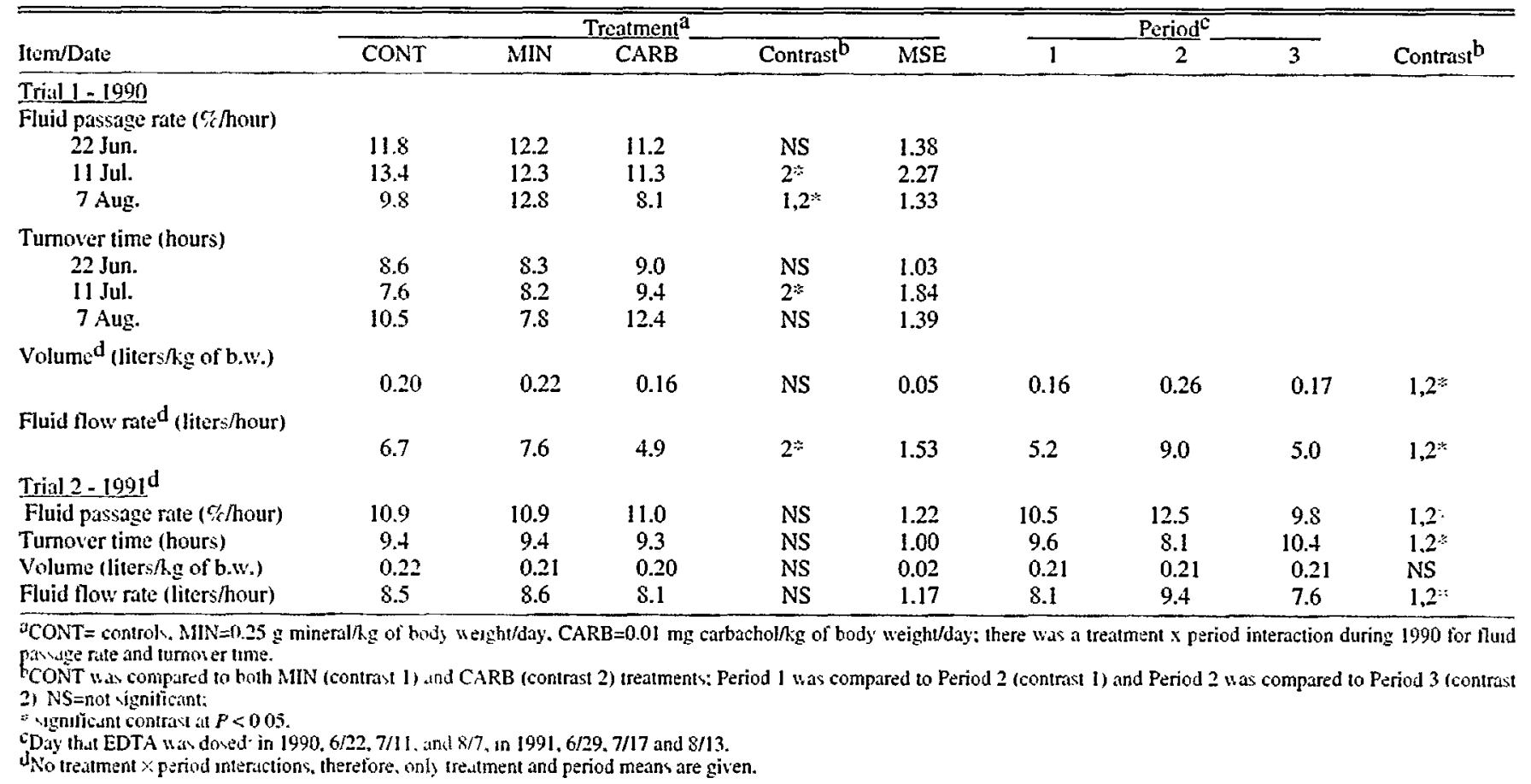


Table 2. Ruminal $\mathrm{pH}$, daily water intake (liters/kg of body weight), and saliva production (liters/day) for cattle receiving carbachol or mineral during 1990 or 1991 in western Colorado.

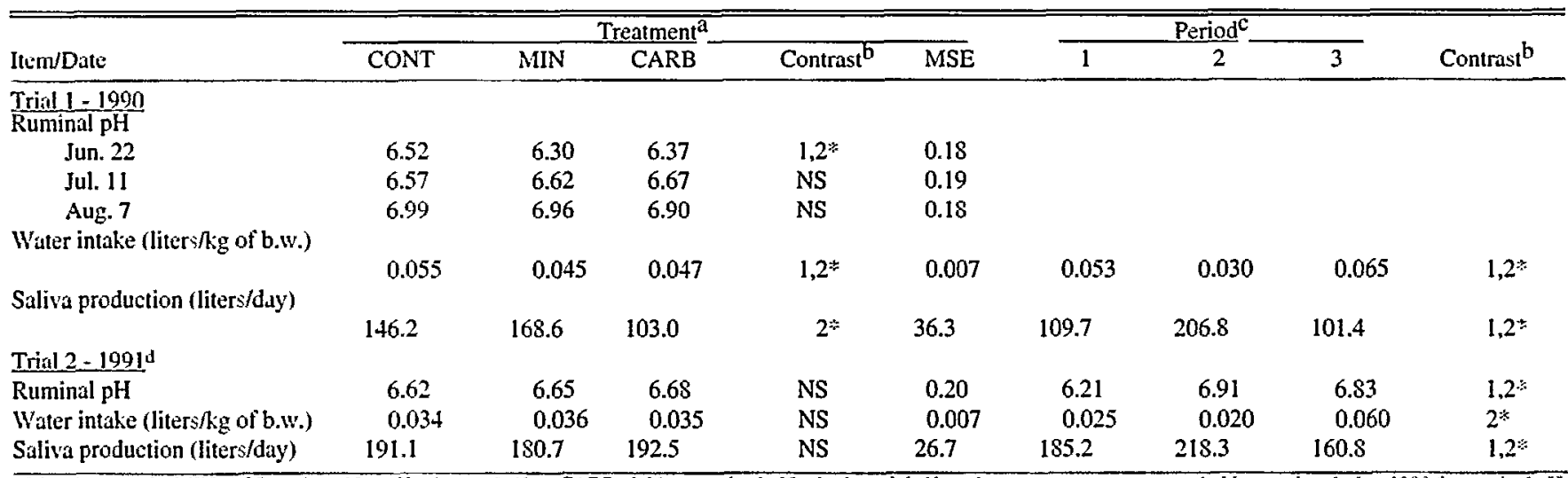

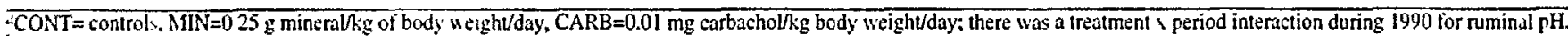
LCONT was compared to both MIN (contrast I) and CARB (contrast 2) treatments: Period 1 was compared to Period 2 (contrast 1 ) and Period 2 was compared to Period 3 (contrist 2) NS=not signilicant, * significant at $P<0.05$.

'For ruminal $\mathrm{pH}, 1990$ periods comespond to $6 / 22.7 / 11$, and $8 / 7 ; 1991$ periods correspond to $6 / 29,7 / 17$ and $8 / 11$. For saliva production and water intake, 1990 periods correspond to 6/23-24.7/13-14, and 8/2-3:1991 periods correypond to $7 / 1-2,7 / 22-23$, and 8/10-11.

dNo treatment $x$ period interactions. therefore, only' treatment and period means are given.

There was a period effect, but no period $\times$ treatment interaction for water intake and saliva production. Water intake for the controls was $13 \%$ greater than for the carbachol group and $18 \%$ greater than for mineral-salt treatment (Table 2). Saliva production was greater in the controls than in the carbachol group (Table 2).

There were no period $x$ treatment interactions for serum variables. Serum $\mathrm{Na}$ and $\mathrm{K}$ concentrations were less for the controls than for the carbachol group, but the controls did not differ from the mineral-salt group (Table 3 ). No treatment effects were noted for $\mathrm{Cl}, \mathrm{Ca}$ or $\mathrm{Mg}$. Period effects were noted for $\mathrm{Na}$ and $\mathrm{Mg}$.

Cattle ate no larkspur during summer, 1990 (Table 4), although larkspur was abundant in the pasture (Table 5). There were no period $\times$ treatment interactions for bites of grasses, forbs, or shrubs. Diets consisted mainly of forbs $(57 \%)$ and grasses $(42 \%)$ (Table 4). Compared with grass, larkspur plant material in August had numerically higher concentrations of all measured minerals (Table 5).

\section{Trial 2 (1991)}

There were no treatment $x$ period interactions for ruminal fluid variables, and no differences among treatments were found during 1991 (Table 1). Period effects were noted for all variables except for volume. Similarly, we noted no period $x$ treatment interactions or treatment effects for ruminal $\mathrm{pH}$, water intake, or saliva production (Table 2). There were period effects for ruminal $\mathrm{pH}$, water intake, and saliva production.

No treatment $x$ period interactions were noted for serum variables (Table 3). The carbachol treatment decreased serum $K$ about $15 \%$ compared with the controls, whereas the mineral-salt treatment had decreased calcium concentrations compared with the controls. Except for $\mathrm{Na}$, serum mineral concentrations on 1

Table 3. Serum electrolyte concentrations (mg/dl: Ca, $\mathrm{Mg}$; meq/liter: $\mathrm{Cl}, \mathrm{K}, \mathrm{Na}$ ) in cattle receiving either carbachol or mineral during 1990 or 1991 in western Colorado.

\begin{tabular}{|c|c|c|c|c|c|c|c|c|c|}
\hline \multirow[b]{2}{*}{ Item/Date } & \multicolumn{5}{|c|}{ Treatment ${ }^{\mathrm{a}}$} & \multicolumn{3}{|c|}{ Perind $^{\mathrm{C}}$} & \multirow[b]{2}{*}{ Contrast $^{b}$} \\
\hline & CONT & MIN & CARB & Contrast $^{\mathrm{b}}$ & MSE & 1 & 2 & 3 & \\
\hline $\begin{array}{l}\text { Trial 1 - 199nd } \\
\text { Sodium (meq/liter) }\end{array}$ & 140.8 & 141.9 & 143.2 & $2 *$ & 1.79 & 143.2 & 137.8 & 144.9 & $1,2^{*}$ \\
\hline Chlorido(meg/liter) & 99.0 & 99.1 & 99.2 & NS & 0.23 & 99.1 & 99.0 & 99.2 & NS \\
\hline Cálcium (mg/dl) & 9.6 & 9.5 & 9.7 & NS & 0.20 & 9.7 & 9.6 & 9.5 & NS \\
\hline Magnesium (mg/dl) & 2.3 & 2.2 & 2.3 & NS & 0.17 & 1.8 & 2.2 & 2.7 & $1 *$ \\
\hline \multicolumn{10}{|l|}{ Trial 2-1991 ${ }^{d}$} \\
\hline Potassium(meq/liter) & 4.1 & 4.3 & 3.5 & $2^{*}$ & 0.32 & 4.3 & 3.6 & 3.9 & $1=:$ \\
\hline Chloride(meq/iler) & 102.8 & 103.2 & 103.8 & NS & 1.26 & 102.1 & 103.7 & 103.9 & $1 *$ \\
\hline Calcium (mg/dl) & 9.6 & 9.3 & 9.6 & $1 *$ & 0.28 & 9.7 & 9.5 & 9.3 & $1^{*}$ \\
\hline Magnesium (mg/dl) & 2.7 & 2.5 & 2.8 & NS & 0.18 & 2.3 & 2.8 & 2.9 & $1: *$ \\
\hline
\end{tabular}

a CONT $=$ control, $\mathrm{MIN}=025 \mathrm{~g}$ mineral $/ \mathrm{kg}$ body weight/duy, $\mathrm{CARB}=0.01 \mathrm{mg}$ carbachol/kg body weight/day.

b CONT was compared to both MIN (contrast 1 ) and CARB (contrast 2) treatments; Period 1 was compared with Period 2 (contrast 1) and Period 2 was compared with Period 3 (contrast 2). NS=not sigmiticant: * signiticant at $P<0 n$ is

c 1990 periods come spond to 7/1. 7/19. and 8/6; 1991 penods correspond to 7/1, 7/18 and 8/14.

d No treatment $\ltimes$ period interactions, therefore, only treatment and period means are given. 
Table 4. Cattle diets ( $\%$ of bites) during 1990 and 1991 in western Colorado.

\begin{tabular}{|c|c|c|c|c|c|c|c|c|c|c|}
\hline \multirow[b]{2}{*}{ Item/Date } & \multicolumn{5}{|c|}{ Treatment } & \multicolumn{4}{|c|}{ Period $^{c}$} & \multirow[b]{2}{*}{ Contrast $^{b}$} \\
\hline & CONT & MIN & CARB & Contrast $^{b}$ & MSE & 1 & 2 & 3 & 4 & \\
\hline Trial $1-1990^{\mathrm{d}}$ & \multirow{2}{*}{\multicolumn{5}{|c|}{$0_{0} \cdots$}} & \multicolumn{4}{|c|}{ (\% of bites $) \cdots$} & \\
\hline Larkspur & & & & & & 0 & 0 & 0 & 0 & \\
\hline Other Forbs & 57 & 57 & 57 & NS & 7.6 & 55 & 63 & 63 & 49 & $2,3 *$ \\
\hline Shrubs & $<1$ & $<1$ & $<1$ & NS & 0.3 & $<1$ & $<1$ & $<1$ & $<1$ & NS \\
\hline \multicolumn{11}{|l|}{ Trial 2-1991d } \\
\hline Other Forbs & 47 & 47 & 44 & NS & 4.7 & 53 & 50 & 50 & 29 & $1,2,3^{*}$ \\
\hline Shrubs & 5 & 7 & 5 & NS & 2.5 & $<1$ & 3 & 8 & 11 & $1,2,3^{*}$ \\
\hline
\end{tabular}

CONT = controls, $\mathrm{MIN}=0.25 \mathrm{~g}$ mineral/kg of body welght/day, CARB=0.01 $\mathrm{mg}$ carbachol/kg of body weight/day.

b CONT was compared to bolh $M I I N$ (contrast 1 ) and CARB (contrast 2) treatments: period 1 was compared with period 4 (contrast 1 ), period 2 was compared with period 4 (contrast 2). and period 3 was compared with period 4 (contrast 3 ): NS=not significant: $*$ significant at $P<0.05$.

c 1990 periods comespond to $6 / 21-30,7 / 1-10,7 / 11-21$, and $7 / 22$ to $8 / 7 ; 1991$ periods comespond to $6 / 26$ to $7 / 5,7 / 6-18,7 / 19$ to $8 / 1$, and $8 / 2-14$, See text for larkspur phenological stages.

No treatment $x$ period interactions, therefore, only treatment and period means are given.

July were different from concentrations in samples taken several weeks later (Table 3).

There was a distinct period effect for larkspur consumption, as cattle consumed little or no larkspur until August, when larkspur matured into the pod stage (Table 4). Neither period $x$ treatment interactions nor treatment differences in cattle diets were found for any diet variable. Consumption of shrubs increased late in the trial, whereas forb consumption (other than larkspur) decreased by over $40 \%$ (Table 4 ).

There were no date $x$ forage class interactions for any mineral variable. The $\mathrm{Ca}$ and $\mathrm{Mg}$ concentration of forage classes ranked larkspur $>$ other forbs $>$ grass (Table 5). The $\mathrm{K}$ concentration of larkspur and forbs did not differ, and was greater than for grass. Forage class had no influence on $\mathrm{Na}$ concentration. Phosphorus concentration tended $(P=0.06)$ to be greatest in other forb samples and least in grass. Calcium concentration increased 55 to $95 \%$ in all forage classes during the summer, whereas $\mathrm{P}$ concentration decreased 15 to $40 \%$ in all forage classes (data not shown).

\section{Discussion}

Carbachol administration either had no effect (1991) or decreased ruminal fluid passage rate, fluid flow rate, saliva production, and water intake (1990) compared with controls. These findings contrast those of Weidmeier et al. (1987), who found that carbachol administered to dairy cows increased saliva production and fluid rate of passage. Possible effects of carbachol on water intake have not been studied.

Overall, ruminal $\mathrm{pH}$ for controls in the study of Wiedmeier et al. $(1987 ; 6.53)$ was similar to the $\mathrm{pH}$ we found in the controls in June (6.52), indicating the highly fermentable nature of the forage. Contrary to results of the Weidmeier et al. (1987) study, carbachol-treated animals in our study had a lower $\mathrm{pH}(6.37)$ than controls, another indication of decreased salivary flow and buffering in the rumen.

Carbachol has been used to overcome ruminal stasis, and the recommended dose is $0.009 \mathrm{mg} / \mathrm{kg}$ of body weight (i.e., 4 $\mathrm{mg} /$ day; Davis 1993). Carbachol can have negative effects on rumen motility if Jarger doses are used (Davis 1993). Our daily dose of $0.01 \mathrm{mg} / \mathrm{kg}$ was slightly higher than the recommended dose, but it seems unlikely that this increase would result in decreased ruminal motility.

Dietary differences likely were a major factor in differences between our study and that of Wiedmeier et al. (1987). The cows used by Wiedmeier et al. (1987) were fed 50\% concentrate diets. Increased concentrate levels often slow passage rate (Goetsch and Galyean 1982), whereas diets consisting entirely of roughage may increase passage rate (Owens and Isaacson 1977). The relationship between diet and passage rate is complex, and it may be difficult to consistently manipulate passage rate in grazing ani-

Table 5. Standing crop ( $\mathrm{kg} / \mathrm{ha} \pm \mathrm{SE}$ ) and mineral content (air-dry basis) of composite clipped forage samples during summer, 1990 and 1991 on larkspur-infested rangeland in western Colorado.

\begin{tabular}{|c|c|c|c|c|c|c|c|}
\hline \multirow[b]{2}{*}{ Item } & \multicolumn{2}{|c|}{ Sampling Period } & \multicolumn{5}{|c|}{ Mineral } \\
\hline & Begind & End & $\mathrm{Ca}$ & $\mathrm{K}$ & $\mathrm{Mg}$ & $\mathbf{P}$ & $\mathrm{Na}$ \\
\hline 1990 & \multicolumn{2}{|c|}{$\ldots \ldots(\mathrm{kg} / \mathrm{h} \mathrm{h})=\ldots \ldots$} & \multicolumn{4}{|c|}{ 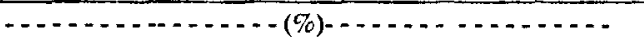 } & $(\mathrm{mg} / \mathrm{kg})$ \\
\hline Grasses & $438 \pm 55$ & $324 \pm 45$ & 0.38 & 1.31 & 0.12 & 0.18 & 540 \\
\hline Forbs $\mathrm{e}$ & $942 \pm 81$ & $521 \pm 120$ & & & & & \\
\hline Larkspur & $590 \pm 219$ & $386 \pm 214$ & 2.92 & 1.71 & 0.35 & 0.33 & 840 \\
\hline \multicolumn{8}{|l|}{1991} \\
\hline Grasses & $400 \pm 53$ & $350 \pm 108$ & $0.48^{\mathrm{c}}$ & $1.12^{\mathrm{b}}$ & $0.13^{\mathrm{c}}$ & $0.25^{b}$ & $300^{a}$ \\
\hline Forbs & $1124 \pm 116$ & $272 \pm 72$ & $1.11^{\mathrm{b}}$ & $1.45^{\mathrm{a}}$ & $0.22^{b}$ & $0.31^{\mathrm{a}}$ & $330^{\mathrm{a}}$ \\
\hline Larkspur & $729 \pm 230$ & $2004 \pm 726$ & $1.48^{a}$ & $1.57^{\mathrm{a}}$ & $0.28^{a}$ & $0.30^{\mathrm{ab}}$ & $360^{\mathrm{b}}$ \\
\hline
\end{tabular}

the Means in the same column with different superscript differ $(P<0.05)$.

d The 1990 study began on Jun. 21 and ended Aigg 7 , the 1991 study began Jun. 26 and ended Aug. 14.

e Forb camples were inadvertently discarded. 
mals (Estell and Galyean 1985).

Serum electrolytes were generally not affected by carbachol treatment, except for $\mathrm{K}$. Carbachol administration increased $\mathrm{K}$ concentration during the first trial, but decreased $\mathrm{K}$ concentration during the second trial. Wiedmeier et al. (1987) also found that serum electrolytes were unaffected by carbachol. Serum values for all electrolytes were within normal ranges, indicating that animals were within homeostatic limits.

The refusal of cattle to eat larkspur during 1990 is consistent with our previous observations that cattle consume little or no larkspur during drought (Pfister and Manners 1991). Spring and early summer precipitation was $56 \%$ of normal, and June temperatures were greater than normal in Yampa (NOAA 1990). We speculate that the dry, warm summer was a factor in decreased larkspur consumption. Larkspur consumption during 1991 peaked during the pod stage, a result that is consistent with other grazing studies we have conducted (Pfister et al. 1988a,b; Pfister and Manners 1991). Unlike these other studies, cattle ate nearly all leaves and few flowers or pods (data not shown).

The results from the supplemental mineral-salt treatment were similar to previous year's studies in Idaho and Utah (Pfister and Manners 1991). The addition of mineral salt did not influence ruminal passage rate, $\mathrm{pH}$, saliva production, serum electrolyte concentrations, nor increase water intake. In 4 summer trials (i.e., the present study and studies by Pfister and Manners 1991), we have not found consistent increases in fluid passage rate with increased dietary levels of mineral salts; this result is contrary to the findings of others (Harrison et al. 1976, Rogers et al. 1979). The present study confirmed our previous finding that mineralsalt supplementation does not decrease the amount of larkspur consumed by grazing cattle. If such mineral-salt supplements decrease cattle susceptibility to larkspur, the protective mechanism is unknown.

Cook and Harris (1968) showed that forbs had a $35 \%$ greater $P$ concentration than did grass on mountain range either early or late in the summer grazing period. Our data also show that forbs, including larkspur, contain higher concentrations of minerals than grasses. Some have postulated that cattle may eat larkspur because of higher mineral concentrations compared with other forage (Logan 1973, Knowles 1974), perhaps as a result of a 'specific hunger' (Denton and Sabine 1963) for an unspecified mineral. A 400-kg cow requires 29,23, 13.4, and $7.3 \mathrm{~g} /$ day of $\mathrm{Ca}$, $\mathrm{P}, \mathrm{Mg}$, and $\mathrm{Na}$, respectively (Georgievskii et al. 1982). Forbs (besides larkspur) are always a major component of grazing cattle diets during summer on tall larkspur-infested rangeland (Ralphs and Pfister 1992). Assuming a dry matter intake of $12 \mathrm{~kg} / \mathrm{day}$, a diet composed of equal parts grass and forbs (excluding larkspur) would be adequate for $\mathrm{Ca}, \mathrm{P}$, and $\mathrm{Mg}$, but not for $\mathrm{Na}$. The $\mathrm{Na}$ concentration of larkspur was generally greater than in forbs (Table 5); however, it seems unlikely that cattle would seek out larkspur as a Na source. Control animals ate no larkspur during 1990 when larkspur had a relatively high $\mathrm{Na}$ concentration $(0.084 \%)$.

In summary, either negative or neutral effects resulted from subcutanenus infusion of carbachol in grazing beef cattle. Carbachol did not stimulate fluid rate of passage, and other potential concomitant effects were absent. Carbachol administration does not appear to have potential as a means of preventing larkspur intoxication in cattle. We cannot recommend mineralsalt supplementation to decrease cattle deaths to tall larkspur. Mineral-salt supplements should be fed as necessary to meet nutritional needs, not to protect livestock against effects of tall larkspur.

\section{Literature Cited}

Anderson, E.C. 1982. Forty million cows can't be wrong! Anderson Research Laboratory. Bozeman. Mont. (mimeo)

Cook, C.W., and L.E. Harris. 1968. Nutritive value of seasonal ranges. Utah Agr. Exp. Sta. Bull. 472. Logan, Ut.

Croom, W.J., Jr., M.A. Froetschel, and W.M. Hagler. 1990. Cholinergic manipulation of digestive function in ruminants and other domestic livestock: a review. J. Anim. Sci. 68:3023-3032.

Davis, L.E. 1993. Drugs affecting the digestive system. pp. 758-761. In: J.L. Howard (ed.), Current Veterinary Therapy: Food Animal Practice 3. W.B. Saunders, Philadelphia.

Denton, D.A., and J.R. Sabine. 1963. The behavior of Na deficient sheep. Behaviour 20:364-367.

Dobelis, P., J.E. Madl, G.D. Manners, J.A. Pfister, and J.P. Walrond. 1993. Antagonism of nicotinic receptors by Delphinium alkaloids. Neurosci. Abstr. 631:12.

Estell, R.E., and M.L. Galyean. 1985. Relationship of rumen fluid dilution rate to rumen fermentation and dietary characteristics of beef cattle. J. Anim. Sci. 60:1061-1071.

Gerring, E.L. 1989. Effects of pharmacological agents on gastrointestinal motility. Vet. Clinics N. Amer.-Equine Prac. 5:283-294.

Goetsch, A.L., and M.L. Galyean. 1982. Effect of dietary concentrate level on rumen fluid dilution rate. Can. J. Anim. Sci. 62:649-652.

Georgievskii, V.I., B.N. Annenkov, and V.I. Samokhin. 1982. Mineral nutrition of animals. Butterworths, Boston.

Harrison, D.G., D.E. Beever, D.J. Thomson, and D.F. Osbourn. 1976. Manipulation of fermentation in the numen. J. Sci. Food Agr. 27:617-620.

Jacques, K., D.L. Harmon, W.J. Croom, Jr., and W.M. Hagler, Jr. 1989. Estimating salivary flow and ruminal water balance of intake, diet. feeding pattern. and slaframine. J. Dairy Sci. 72:443-452.

Knowles, K. 1974. An evaluation of larkspur poisoning in cattle and trampling damage that occurs during grazing on a summer range in eastern Idaho. M.S. thesis. Univ. of Idaho, Moscow.

Logan, J.R. 1973. Evaluation of a specifically-formulated supplement for the prevention of larkspur poisoning in cattle. M.S. thesis. Utah State Univ.. Logan.

Manners, G.D., K.E. Panter, M.H. Ralphs, J.A. Pfister, J.D. Olsen, and L.F. James. 1993. The occurrence and toxic evaluation of norditerpenoid alkaloids in the tall larkspurs (Delphinium spp.). J. Agr. Food Chem. 41:96-100.

Manners, G.D., and J.A. Pfister. 1993. Normal phase liquid chromatographic analysis of toxic norditerpenoid alkaloids. Phytochem. Anal. 4:14-18.

Manners, G.D., J.A. Pfister, M.H. Ralphs, K.E. Panter, and J.D. Olsen. 1992. Larkspur chemistry: toxic alkaloids in tall larkspurs. J. Range Manage. 45:63-66.

NOAA. 1990. Climatological Data Annual Summary. Colorado. National Climatic Data Center. Asheville, N.C.

Owens, F.N., and H.R. Isaacson. 1977. Ruminal microbial yiclds: factors influencing synthesis and bypass. Fed. Proc. 36:198-202.

Pfister, J.A., and G.D. Manners. 1991. Mineral supplementation of cattle grazing larkspur-infested rangeland during drought. J. Range Manage. 44:105-111.

Pfister, J.A., G.D. Manners, D.R. Gardner, and M.H. Ralphs. 1994c. Toxic alkaloid levels in tall larkspur (Delphinium barbeyi) in western Colorado. J. Range Manage. 47:355-358.

Pfister, J.A., G.D. Manners, M.H. Ralphs, Z.X. Hong, and M.A. Lane. 1988a. Effects of phenology, site and rumen fill on tall larkspur consumption by cattle. J. Range Manage. 41:509-514.

Pfister, J.A., K.E. Panter, and G.D. Manners. 1994a. Effective dose in cattle of toxic alkaloids from tall larkspur (Delphinitun barbeyi). Vet. Hum. Toxicol. 36:10-11.

Pfister, J.A., K.E. Panter, G.D. Manners, and C.D. Cheney. 1994b. Reversal of tall larkspur (Delphinitm barbeyi) toxicity with physostigmine. Vet. and Hum. Toxicol. 36:511-514.

Pfister, J.A., M.H. Ralphs, and G.D. Manners. 1988b. Cattle grazing tall larkspur on Utah mountain rangelands. J. Range Manage. 41:118-122.

Ralphs, M.H., and J.A. Pfister. 1992. Cattle diets in tall forb communities on mountain rangelands. J. Range Manage. 45:534-537. 
Ralphs, M.H., J.D. Olsen, J.A. Pfister, and G.D. Manners. 1988. Plant-animal interactions in larkspur poisoning in cattle. J. Anim. Sci. $66: 2334-2342$.

Rogers, J.A., B.C. Marks, C.L. Davis, and J.H. Clark. 1979. Alteration of rumen fermentation in steers by increasing rumen fluid dilution rate with mineral salts. J. Dairy Sci. 62:1599-1605.

Taylor, P. 1990. Cholinergic agonists. pp. 122-130. In: Gilman, A.G., T.W. Ralls, A.S. Nies, and P. Taylor (eds.), The Pharmacological Basis of Therapeutics, Eighth Ed. Pergamon Press, N.Y.
Theeuwes, F., and S.I. Yum. 1976. Principles of the design and operation of generic osmotic pumps for the delivery of semisolid or liquid drug formulations. Ann. Biomed. Eng. 4:343-353.

Uden, P., P.E. Colucci, and P.J. Van Soest. 1980. Investigation of chromium, cerium, and cobalt as markers in digesta rate of passage studies. J. Sci. Food Agr. 31:625-631.

Wiedmeier, R.D., M.J. Arambel, R.C. Lamb, and D.P. Marcinkowski. 1987. Effect of mineral salts, carbachol, and pilocarpine on nutrient digestibility and ruminal characteristics in cattle. J. Dairy Sci. 70:592-600.

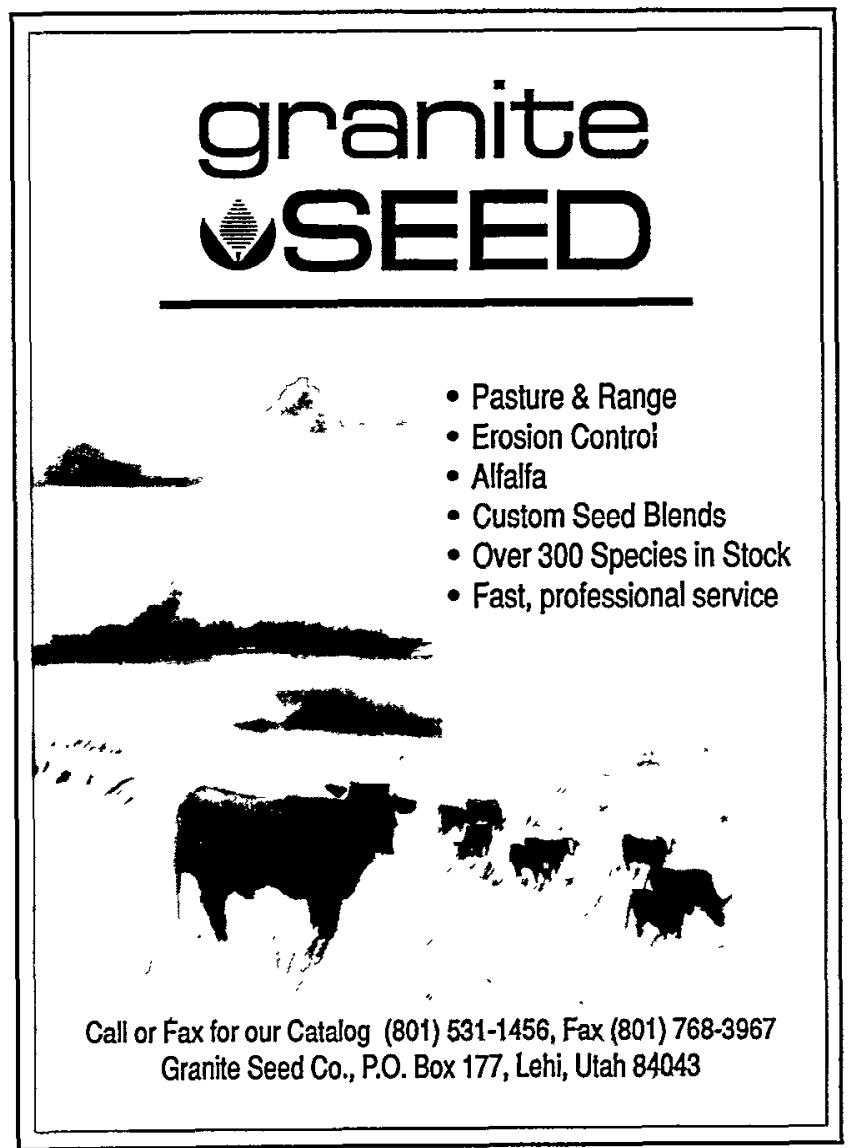

